\title{
Cytotoxicity analysis of electrostatically applied epoxy coating onto CO-CR alloy
}

\author{
Análise da citotoxidade de pintura epóxi na aplicação eletrostática sobre liga de CO-CR
}

Êrica Wehmuth RAGONHA ${ }^{1}$

Elizabeth Ferreira MARTINEZ2

Carlos Alberto MUZILLI'

Milton Edson MIRANDA'

Karina Andrea Novaes OLIVIERI ${ }^{1}$

\section{ABSTRACT}

\section{Objective}

To investigate the biological effect of a new method to camouflage the cobalt-chromium (CoCr) metal structure of an RPD, onto which an electrostatic paint was applied.

\section{Methods}

In vitro cytotoxicity of epoxy Politherm NOBAC30C (Weg Industries SA, Santa Catarina, Brazil) in combination with polished CoCr was tested by placing it in contact with cultured human fibroblasts and comparing it with polystyrene (control surface). The cells were cultured in the presence of the test surfaces for 24, 48, 72, 94 and 120 hours. The number of viable and non-viable cells was established by manual counting. The Tukey test was used to statistically analyze cell counts between the groups.

\section{Results}

The results showed that cell proliferation was similar between the groups ( $p=0.2174)$. It was observed that at 24,48 and $72 \mathrm{~h}$, there was no significant increase in cell proliferation in all groups. From 96 to $120 \mathrm{~h}$, an increase in cell proliferation was observed in all groups, with no significant difference between them ( $p>0.05)$.

\section{Conclusion}

The epoxy paint studied showed no cytotoxicity in vitro.

Indexing terms: Denture partial removable. Epoxy compounds. Esthetics dental. Toxicity tests.

\section{RESUMO}

\section{Objetivos}

Analisar, biologicamente, a possibilidade do uso de pintura por aplicação eletrostática.

\section{Métodos}

Por meio de testes in vitro de citotoxicidade, comparando o comportamento da tinta epóxi Politherm 30 Nobac C (Weg Indústrias S.A, Santa Catarina, Brasil) com CoCr polido e poliestireno em contato com cultura de fibroblastos humanos. Esse teste foi realizado através de contagem de células viáveis e não viáveis em tempos de 24, 48, 72, 94 e 120 horas. Para a contagem de células viáveis foi aplicada a Análise Estatística de Tukey.

\section{Resultados}

Os resultados obtidos na presente pesquisa mostraram que o comportamento de crescimento celular foi estatisticamente semelhante entre grupos $(p=0,2174)$. Observou-se que nos tempos de 24,48 e 72 horas, não houve aumento estatisticamente significante da proliferação celular, mantendo-se o padrão para todos os grupos estudados. A partir de 96 e $120 \mathrm{~h}$ observamos um aumento da proliferação celular para todos os grupos estudados, sem diferenças entre os mesmos também ( $p>0,05)$. Para os resultados de células inviáveis, aplicou-se a Análise não Paramétrica de Kruskal Wallis e o teste de Dunn, devido à baixa taxa de morte celular, sem diferença estatisticamente entre os grupos $(p>0,05)$.

\section{Conclusão}

Conclui-se, portanto, que a pintura Epóxi estudada não apresentou citotoxicidade para os testes realizados in vitro.

Termos de indexação: Prótese parcial removível. Compostos de Epóxi. Estética dentária. Testes de toxicidade

\footnotetext{
${ }^{1}$ Faculdade São Leopoldo Mandic, Curso de Odontologia, Programa de Pós-Graduação em Prótese Dentária. Rua José Rocha Junqueira, 13, Swift, 13045-755, Campinas, SP, Brasil. Correspondência para / Correspondence to: KAN OLIVIERI. E-mail: <karina_olivieri@hotmail.com>.

${ }^{2}$ Faculdade São Leopoldo Mandic, Curso de Odontologia, Departamento de Microbiologia. Campinas, SP, Brasil.
} 


\section{INTRODUCTION}

Advances in dental materials come from combining the functional and aesthetic needs of patients when providing them with prosthetic apliances. Studies relating to mechanical and functional aspects of Removable Partial Dentures (RPD) have led to the belief that clasp-retained metal structures are the most stable RPD type and cause fewest injuries to the remaining abutment teeth ${ }^{1-2}$.

Various methods to improve the esthetically displeasing appearance of RPDs have been studied. An attempt to eliminate the metal structure reappeared with the advent of flexible resins. Despite a lack of longitudinal studies, such appliances are regarded as esthetically satisfactory, but leave something to be desired with regards to durability and protection of the abutment teeth ${ }^{3-4}$.

Other ways to achieve aesthetics in RPDs include overdentures, Dolder bars and intracoronal attachments. These usually involve purposely wearing the tooth and additional costs, due to the increased complexity of such an approach ${ }^{5}$.

Therefore, a material as flexible as the RPD structure, or even more so, which adheres to it, such as electrostatically applied epoxy paint, became the focus of this study, so that a part, such as the prototype (Figure 1) could be used clinically.

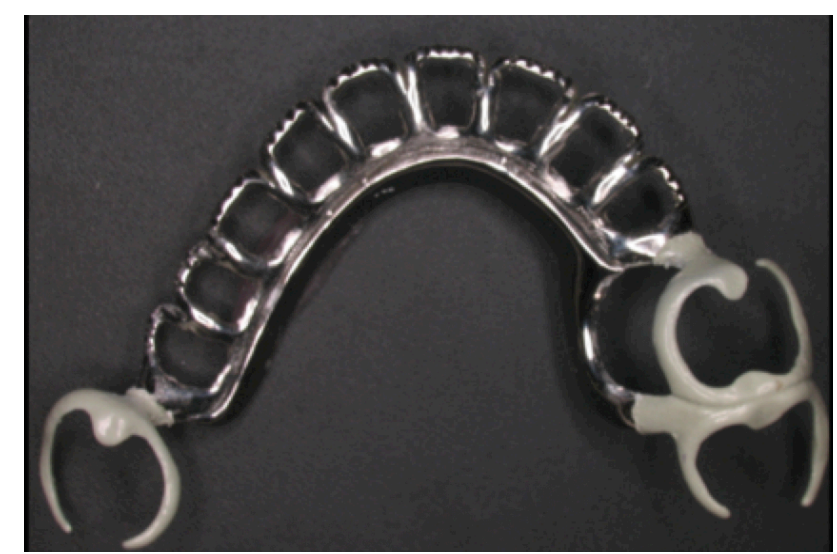

Figure 1. RPD prototype with electrostatic paint application.

The process of electrostatic paint application promotes a more uniform and lasting finish, both on some metals and on wood. Powdered paints became available in the 1950s and use the principle of attraction and repulsion of electrical charges ${ }^{6-7}$.

In order for such new technology to be used in the oral cavity, in addition to its mechanical and functional aspects, precaution must be taken to clarify whether it is biocompatible with the oral tissues ${ }^{8-10}$. Amongst the biocompatibility analyses, cytotoxicity tests relating to allergenic and carcinogenic potentials are essential ${ }^{11-12}$.

The aim of this study was to verify in vitro, the cytotoxicity of Epoxy coating for use on RPD metal structures, by means of cell viability, using primary cultures of human gingival fibroblasts.

\section{METHODS}

Sixty disc-shaped specimens ( $8 \mathrm{~mm}$ in diameter by $2 \mathrm{~mm}$ thick) were cast in Cobalt-Chrome alloy (Co-Cr) and Fit-Flex (Talladium - Brazil) using the lost wax technique.

The 60 cast specimens were carefully cleaned using $50 \mu \mathrm{m}$ aluminum oxide (Labordental - São Paulo - Brazil) airborne particle abrasion to remove investment debris.

Two groups $(n=30)$ were formed according to the alloy surface treatment: Group 1- Airbone particle abrasion + paint (Epoxy Politherm 30 Nobac C Paint Weglndústrias S.A - Química, Guaramirim - Santa Catarina, Brazil) (Figure 2); Group 2- polishing as recommended for RPD metal structures ${ }^{13}$ (Figure 3).

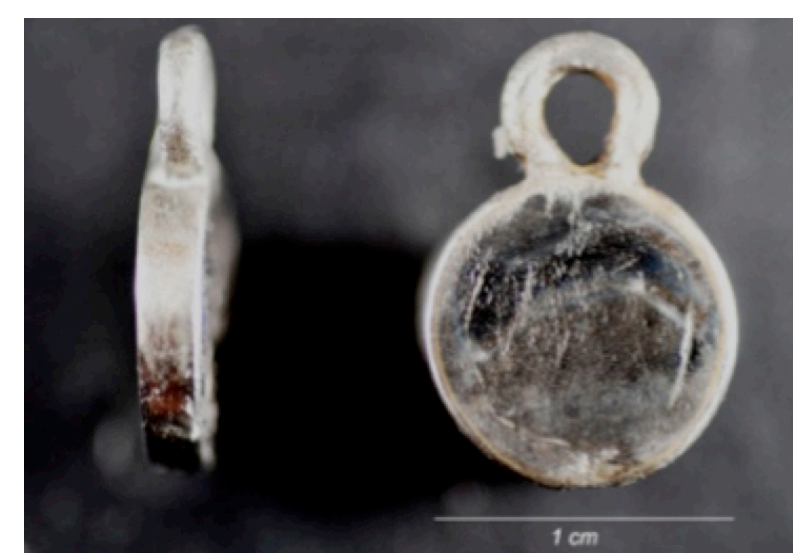

Figure 2. Polished Test specimens.

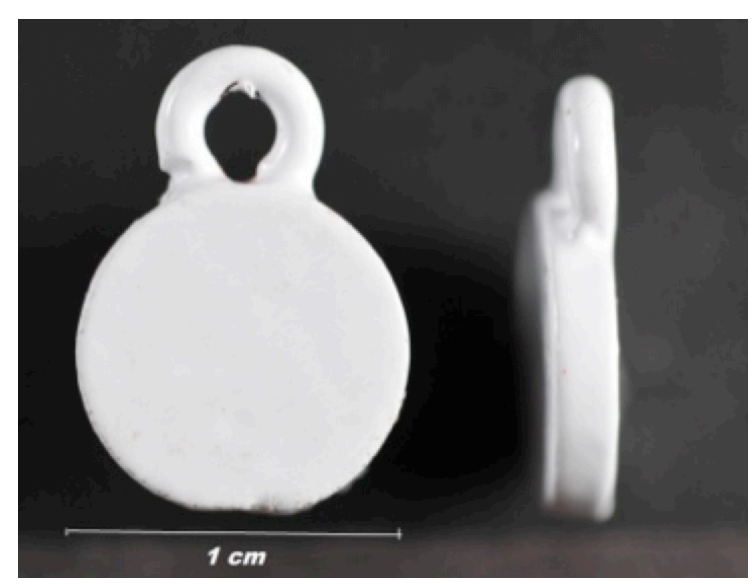

Figure 3. Painted test specimens. 
In the technique of electrostatic painting, parts or substrates, terms more commonly used, are placed on continuous convey or sand and then taken into a paint booth. These carriers are grounded because the earth is a good conductor of electricity and will, therefore, attract the paint, forming a layer adhered electrostatically. Paint powder receives a negative electrical charge applied by an electrode that reaches 20-90KV. When the paint is directed to the substrate, an electrostatic field "Rain ions" is formed by the negative polarity electric charges, based on the principle attraction and repulsion of electric charges, therefore covering the surface.

\section{Citotoxicity tests}

These tests were based on the method described by Freshney ${ }^{13}$, using cells previously harvested from a host and cultivated in the laboratory.

Briefly, cells were isolated from the gingiva of three different patients using the explant technique of primary cell culture. The patients consented to the use of their tissue and prior approval from the Research Ethics Committee of the São Leopoldo Mandic Research Institute and Dental Research Center was obtained (CEP-No. Protocol: 2009/0083). The fibroblasts were cultured according to the method of Martinez \& Araújo ${ }^{14}$, in Dulbecco's Modified Eagle's Medium (DMEM, Sigma Chemical Co, St Louis, MO, USA), supplemented with 10\% fetal bovine serum (Cultilab, Campinas) and $1 \%$ antibiotic-antimicotic solution $\left(\text { Sigma }^{\circ}\right)^{13}$.

When the cell culture reached subconfluence, the cells were enzymatically removed from the culture flasks, counted in a hemocytometer (Fisher Scientific, Pittsburgh, PA, USA) and used for the following cytotoxicity experiments.

The experiment was performed in triplicate wells containing culture medium and either the painted $\mathrm{Co}-\mathrm{Cr}$ specimens or the polished $\mathrm{Co}-\mathrm{Cr}$ specimens. The control groups comprised only culture medium in polystyrene (Figure 4).

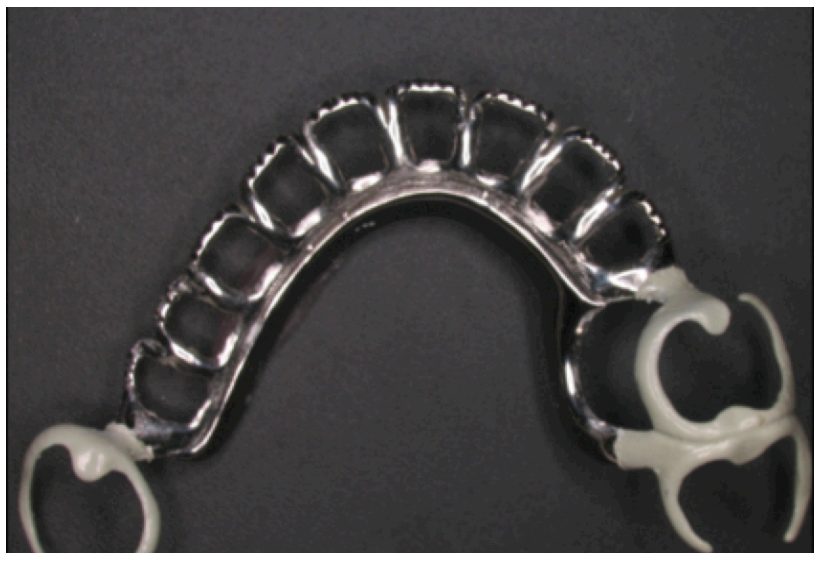

Figure 4. Mounted plate.
The method of vital exclusion by Trypan blue was used to evaluate cell proliferation of fibroblast in contact with epoxy paint at time intervals of $24 \mathrm{~h}, 48 \mathrm{~h}, 72 \mathrm{~h}, 90 \mathrm{~h}$ and $120 \mathrm{~h}$. The cells were enzymatically removed from the wells, centrifuged and resuspended in $1 \mathrm{ml}$ of medium. From the cell suspension, a 10- $\mu$ l sample was removed and added to $10 \mu \mathrm{l}$ of Trypan blue; then $1 \mu \mathrm{l}$ of this suspension was placed in a hemocytometer (Neubauer-Fisher Scientific Chamber, Pittsburgh, PA, USA) for cell counting on an inverted phase microscope (Nikon, Eclipse TS100). The mean cell count was obtained for the triplicate samples from each group at each study period.

The statistical analysis was performed using Twoway ANOVA $(p=0.05)$ and the Tukey test, at a significance level of $5 \%(p<0.05)$.

\section{RESULTS}

The results of the present study demonstrated that the Epoxy Nobac 30 paint (Weg Indústrias Químicas S A, Guaramirim, Santa Catarina, Brazil) showed no cyctotoxic effect on the cultures of human gingival fibroblasts in vitro.

No increase in cell proliferation in the studied group (Epoxy paint) was observed at the time intervals of 24, 48 and $72 \mathrm{~h}$ in comparison with the control groups (polished and polystyrene specimens). No significant difference was observed between the study groups using the Tukey test (Table 1).

Table 1. Means (standard deviation) of viable cell counts, according to group and time elapsed (hours). Data presented as the mean of biological triplicates

\begin{tabular}{ccccc}
\hline $\begin{array}{c}\text { Time } \\
\text { (hours) }\end{array}$ & $\begin{array}{c}\text { Test specimens } \\
\text { with paint }\end{array}$ & $\begin{array}{c}\text { Polished Test } \\
\text { specimens }\end{array}$ & Polystyrene & Tukey \\
\hline 24 & $\begin{array}{c}5504.4 \\
(4373.5)\end{array}$ & $\begin{array}{c}4888.9 \\
(2240.4)\end{array}$ & $\begin{array}{c}7197.8 \\
(6998.9)\end{array}$ & $\mathrm{B}$ \\
& 7320.0 & 9833.3 & 12010.0 & $\mathrm{Ab}$ \\
48 & $(4244.3)$ & $(4474.0)$ & $(14181.3)$ & \\
& $\begin{array}{c}7646.7 \\
72\end{array}$ & 15755.6 & 11998.9 & $\mathrm{Ab}$ \\
& $(5923.6)$ & $(5554.4)$ & $(8937.2)$ & \\
96 & 19690.0 & 20955.6 & 21396.7 & $\mathrm{Ab}$ \\
& $(17494.4)$ & $(6041.5)$ & $(30250.7)$ & \\
120 & 16208.9 & 40933.3 & 27895.6 & $\mathrm{~A}$ \\
& $(10962.4)$ & $(1545.2)$ & $(27895.6)$ & \\
Tukey & $\mathrm{A}$ & $\mathrm{A}$ & $\mathrm{A}$ & \\
\hline
\end{tabular}

The results from non-viable cell counts showed absence of dead cells (Table 2) confirming that the paint did not have a cytotoxic effect on the studied group (Epoxy), compared with the control groups (polished and polystyrene). 
Table 2. Means (standard deviation) of non viable cell counts, according to group and time elapsed, in hours. Data presented as the mean of biological triplicates.

\begin{tabular}{|c|c|c|c|c|}
\hline $\begin{array}{l}\text { Time } \\
\text { (hours) }\end{array}$ & $\begin{array}{l}\text { Test specimens } \\
\text { with paint }\end{array}$ & $\begin{array}{l}\text { Polished Test } \\
\text { specimens }\end{array}$ & Polystyrene & Tukey \\
\hline 24 & $0(0 ; 1466.7)$ & $0(0 ; 0)$ & $0(0 ; 0)$ & a \\
\hline 48 & $\begin{array}{l}293.3(0 ; \\
733.3)\end{array}$ & $0(0 ; 1466.7)$ & $\begin{array}{c}733.3(220.0 \\
1466.7)\end{array}$ & $a$ \\
\hline 72 & $0(0 ; 146.7)$ & $\begin{array}{l}733.3(0 ; \\
733.3)\end{array}$ & $\begin{array}{l}73.3(0 ; \\
1466.7)\end{array}$ & a \\
\hline 96 & $\begin{array}{c}366.7(0 \\
4400.0)\end{array}$ & $0(0 ; 0)$ & $\begin{array}{c}1466.7(73.3 \\
8666.7)\end{array}$ & a \\
\hline 120 & $0(0 ; 293.3)$ & $\begin{array}{c}733.3(0 ; \\
1466.7)\end{array}$ & $0(0 ; 0)$ & a \\
\hline Tukey & A & A & A & \\
\hline
\end{tabular}

Different letters (capitals horizontally and lower case vertically) indicate no significant difference ( $p>0.05)$.

\section{DISCUSSION}

In terms of prosthetic oral rehabilitation, RPD continues to be well accepted by patients both functionally and esthetically, with some restrictions ${ }^{15-17}$. The restrictions observed are mainly regarding the visible metal structures within the appliance ${ }^{18-20}$.

Camouflage ${ }^{5,21-22}$, positioning ${ }^{23}$ and less visible means of retention 1-3,24-26 have been important research topics since the 1960s. The same applies to the use of intra and extracoronal attachments ${ }^{27-28}$, which can significantly increase treatment costs ${ }^{29-30}$.

Although the Twin-flex clasps are more concealable retainers, they have restricted applications in clinical use. For the very esthetic acetate clasps ${ }^{30}$ there have been no longitudinal studies evaluating their durability and stability to date.

RPDs with a rotational axis, or dual insertion axis, a most interesting esthetic solution for Kennedy Class IV patients has the disadvantage of a poor proximal adaption with the adjacent tooth ${ }^{26,29-30 \text {, }}$.

Although flexible dentures may provide esthetic results in some situations, they also leave something to be desired in terms of mechanics and preservation of abutment teeth, in addition to the lack of support ${ }^{28}$.

In the search for improved esthetics, the cytotoxicity of epoxy paint electrostatically applied to Co$\mathrm{Cr}$ to characterize metal structures for removable partial dentures was evaluated.

Epoxy is a polymer, and its behavior differs from that of other types of materials that have been tested and described in the literature for camouflaging the metal portions of the RPD, such as thermoplastic resins and ceramics, whose flexibility is lower than that required by the clasp. Thus, it is expected that the material being tested may offer better results with respect to the flexural mechanical requirements of the clasp for this denture. Moreover, a thin $0.3-\mathrm{mm}$ coat is sufficient to adequately cover the substrate.

The main reason for using Politherm Nobac 30 epoxy paint in this study was its high flexibility of up to $5 \mathrm{~mm}$, according to the manufacturer. This property led us to believe that the retainer clasp, both for insertion and removal of the dental prosthesis, would be able to withstand the aforementioned movements without damaging the camouflage material, since the flexibility demanded for Co-Cr is $0.25 \mathrm{~mm}$.

In dentistry, the use of epoxy and Teflon includes the prevention of allergic reactions to metal, thus permitting the use of metallic alloys as a treatment option for such patients ${ }^{12}$. Chaves et al. ${ }^{11}$ also concluded that the application of epoxy material onto orthodontic wires diminished their corrosive potential.

In the present study, the cytotoxic effect of electrostatically applied epoxy paint was evaluated. Due to the lack of solvents and heavy materials required to promote polymerization of the material, it should have a strong potential to be biocompatible.

It is known that all dental materials must meet strict criteria in order to be considered as a biomaterial with biocompatibility and bioacceptance properties, since they will be in constant contact with the oral tissues, as part of a dental rehabilitation appliance. There would be no use for a material with perfect capacity for maximum strength or resistance to deformation, but that was harmful to the oral environment or the general health ${ }^{27}$.

Therefore, it is necessary that dental materials undergo cytotoxicity tests before they are considered applicable for clinical use in patients ${ }^{30}$.

Although a cytotoxicity test may show whether a material has biocompatible properties initially, the fact that the action of oral fluids could make it corrosive over time may bring the issue of a possible allergic reaction in the host $^{10}$.

The corrosive effect of Co- $\mathrm{Cr}$ can be diminished if care is taken with finishing and polishing the prosthetic appliance at the time of fabrication, thereby improving biocompatibility.

Therefore, the test specimens of the control group were made of $\mathrm{Co}-\mathrm{Cr}$ and polished as recommended for an 
RPD of high standard, whilst the epoxy paint specimens were prepared following the parameters of Gnecco et al. ${ }^{7}$. Briefly, before electrostatic application of epoxy paint, finishing, cleaning and airborne particle abrasion with aluminum oxide was performed in order to guarantee good adherence of the paint to the substrate, as this can adhere to metals by physical, chemical and mechanical bonds. Cleaning eliminates foreign matter such as contaminants and oxidation. Airborne particle abrasion promotes roughness and increases the contact surface, helping the paint to adhere to its substrate.

It was observed that in the time intervals of 24,48 and $72 \mathrm{~h}$, there was no increase in cell proliferation, and the pattern was maintained for all the studied groups. This is explained by the fact that initially, the cell culture needed to find conditions to adhere to the substrate, spread itself out and then proliferate. For the studied human fibroblasts obtained from primary culture, this time varied from 48 to $72 h^{14}$. Therefore, a low cell growth rate is expected initially in cell culture, irrespective of the cytotoxicity tests.

As from 96 and 120h, an increase in cell proliferation was observed for all the studied groups, with no significant differences $(p \leq 0.05)$ between them and a

\section{REFERENCES}

1. Khan SB, Geerts GA. Aesthetic clasp design for removable partial dentures: a literature review. SADJ. 2005;60(5):190-4.

2. Castillero MEM, Todescan R. Estética em prótese parcial removível (Nota Prévia). Rev Odontol Univ São Paulo.1989;3(3):438.

3. Chu $\mathrm{CH}$, Chow TW. Esthetic designs of removable partial dentures. Gen Dent. 2003;51(4):322-4.

4. Moreno de Delgado M, Garcia LT, Rudd KD. Camouflaging partial denture clasps. J Prosthet Dent.1986;55(5):656-60.

5. Bonachela WC, Araújo CRP, Di Creddo RC, Asckar EM. Uma solução estética para as próteses parciais removíveis.Rev Assoc Paul Cir Dent. 1988;42(6):352-3.

6. Anusavice KJ. Phillips Materiais Dentários. 10ª ed. Rio de Janeiro: Guanabara Koogan; 1998.

7. Gnecco C, Mariano R, Fernandes F. Tratamento de superfície e pintura. Rio de Janeiro: Instituto Brasileiro de Siderurgia /Centro Brasileiro de Construção em Aço; 2003.

8. Bocaz G, Revilla AL, Krejcí J, Havel J. Characterization of a sapphire-epoxy coating for capillary electrophoresis. J Capillary Electrophor. 1998;5(5-6):165-70.

9. Hansi C, Arab A, Rzany A, Ahrens I, Bode C, Hehrlein C. Differences of platelet adhesion and thrombus activation on amorphous silicon carbide, magnesium alloy, stainless steel, low cell death rate throughout, therefore confirming that epoxy paint was biocompatible in vitro.

The biological behavior of this new material is rather promising in the area of dental prosthetic rehabilitation, in addition to biomechanical properties, in order to simulate its use in the oral environment, which could enable epoxy paint to be used in future as an esthetic tool for camouflaging visible metals in RPD and probably reduce corrosion in certain metals, which makes them less biocompatible.

\section{CONCLUSION}

The results from the present in vitro study have shown that epoxy paint on the metal structures (Co-Cr) of Removable Partial Dentures demonstrated no cytotoxicity.

\section{Colaborators}

ÉW RAGONHA, EF MARTINEZ, CA MUZILLI, ME MIRANDA and KAN OLIVIERI They participated in all phases of research. and cobalt chromium stent surfaces. Catheter Cardiovasc Interv. 2009;73(4):488-96. doi: 10.1002/ccd.21834

10. Neves CB, Lopes LP, Ferrão HF, Miranda JP, Castro MF, Bettencourt AF. Ethanol post polymerization treatment for improving the biocompatibility of acrylic reline resins. Biomed Res Int. 2013;2013:485246. doi: 10.1155/2013/485246

11. Chaves CA, Machado AL, Vergani CE, de Souza RF, Giampaolo ET. Cytotoxicity of denture base and hard chairside reline materials: a systematic review. J Prosthet Dent. 2012;107(2):114-27. doi: 10.1016/S0022-3913(12)60037-7

12. Imirzalioglu P, Alaaddinoglu E, Yilmaz Z, Oduncuoglu B, Yilmaz $B$, Rosenstiel S. Influence of recasting different types of dental alloys on gingival fibroblast cytotoxicity. J Prosthet Dent. 2012;107(1):24-33. doi: 10.1016/S0022-3913(12)60013-4

13. Zuim PRJ, Bezzon OL, Sousa V, Garcia AR. Recursos estéticos com próteses parciais removíveis retidas por grampos: eixorotacional. Rev Odontol Araçatuba. 2003;24(1):27-32.

14. Martinez EF, Araújo VC. In vitro immunoexpression of extracellular matrix proteins in dental pulpal and gingival human fibroblasts. Int Endod J. 2004:37(11):749-55. doi: 10.1111/j.1365-2591.2004.00864.x

15. Chee WW, Cho GC. Achieving esthetics with removable partial denture. J Calif Dent Assoc. 1990;18(1):19-22.

16. Cosme DC, Baldisserotto SM, Fernandes EL, Rivaldo EG, Rosing CK, Shinkai RS. Functional evaluation of oral rehabilitation with removable partial dentures after five years. 
J Appl Oral Sci. 2006;14(2):111-6. doi: 10.1590/S167877572006000200009

17. Koyama S, Sasaki K, Kawata T, Atsumi T, Watanabe M. Multi variate analysis of patient satisfaction factors affecting the usage of removable partial dentures. Int J Prosthodont. 2008;21(6):499-500.

18. Freshney RI. Culture of animal cells: a manual of basic technique. New York: Wiley; 2005.

19. Sykora O. Esthetic considerations in the construction of a removable partial denture. Quintessence Int. 1994;25(11):757-62.

20. Zlatarić DK, Celebić A. Factors related to patients' general satisfaction with removable partial dentures:a stepwise multiple regression analysis. Int J Prosthodont. 2008;21(1):86-8.

21. Bonachela WC, Asckar EM, Freitas R, De Carrara CE. Utilização de resina herculite em prótese parcial removível:uma avaliação da resistência ao cisalhamento em 4 ligas de co-cr comerciais. Rev Bras Odontol. 1995;52(3):16-9.

22. Bonachela WC. Uma Solução protética para as próteses parciais removíveis. Rev Assoc Paul Cir Dent. 1998;42(6):392-3.

23. Tran C, LaBarre E, Landesman HM. A removable partial denture using anesthetically design edround-rest distal claspon maxillary anterior abutment teeth: a clinical report. J Prosthet Dent. 2009;102(5):286-9. doi: 10.1016/\$0022-3913(09)60174-8

24. Kratochvil FJ. Influence of occlusal rest position and clasp design on movement of abutment teeth. J Prosthet Dent. 1963;13(1):114-24. doi:10.1016/0022-3913(63)90204-X
25. McCartney JW. The MGR clasp:an esthetic extracoronal retainer for maxillary canines. J Prosthet Dent. 1981;46(5):490-3.

26. Brudvik JS, Palacios R. Lingual retention and the elimination of the visible clasp arm. J Esthet Restor Dent. 2007;19(5):247-54.

27. Zitzmann NU, Rohner U, Weiger R, Krastl G. When to choose which retention element to use for removable dental prostheses. Int J Prosthodont. 2009;22(2):161-7. doi: 10.1111/j.17088240.2007.00112.x

28. Cosme DC, Rivaldo EG, Nakamura EM, Frasca LCF. Prótese parcial removível associada à prótese fixa adesiva através de encaixe extracoronário. Rev Odonto Ciênc. 2005;20(48):187-90.

29. Donovan TE, Derbabian K, Kaneko L, Wright R. Esthetic considerations in removable prosthodontics. J Esthet Restor Dent. 2001;13(4):241-53.

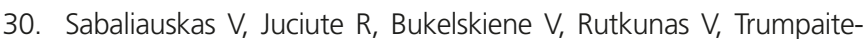
Vanagiene $R$, Puriene $A$. In vitro evaluation of cytotoxicity of permanent prosthetic materials. Stomatologija. 2011;13(3):75-80.

Received on: 13/3/2014

Final version resubmitted on: 19/10/2014

Approved on: 15/2/2015 